\title{
БИОЭНЕРГЕТИКА ЗАСОЛЕННЫХ ПОЧВ
}

ССамедов П. А., канд. с.-х. наук, Институт почвоведение и агрохимии НАН Азербайджана, г. Баку, Азербайджан, samed-bio@yandex.ru

\section{BIOENERGETICS OF SALINE SOILS}

\author{
CSamedov P., Ph.D., Institute of Soil Science and Agrochemistry of ANAS, \\ Baku,Azerbaijan,samed-bio@yandex.ru
}

Аннотащия. В статье приводятся результаты исследований по биоэнергетике засоленных почв серо-бурых и сероземно-луговых почв Сиазань-Сумгаитского массива и Сальянской степи. Сравнительно анализируются энергетические показатели беспозвоночных животных и микроорганизмов засоленных биотопов и окультуренных ценозов. Установлено, что в биотопах с различной степенью засоления энергетические показатели беспозвоночных животных и микробиоты количественно различаются между собой.

Abstract. The article deals with the results of the researches on bioenergetics of the saline grey-brown and sierozem-meadow soils in the Siyazan-Sumgait massive and Salyan steppe. The energetical indications of the invertebrates and microorganisms in saline biotopes and cultivated cenoses are comparative indications of invertebrates and microbiota in biotope with the various degree of salinity quantitatively differ among themselves.

Ключевые слова: биотоп, энергия, засоление, микробиота, беспозвоночные.

Keywords: biotope, energy, salinization, microbiota, invertebrates.

\section{Введение}

При исследовании экологических соотношений между биологическими факторами и засолением почвы особую значимость приобретает изучение возможных связей отдельных видов растений (или комплексов) с характером и степенью засоления, которая необходима для выяснения не только важных вопросов генезиса солевого профиля почв, но и установлении экологической значимости растительных комплексов в формировании зоомикробиоценозов засоленных почв.

Растительность засоленных почв представлена в основном галофитно-солянковыми формациями отличающиеся незначительной продуктивностью и слабой гумификацией надземной фитомассы на создание которой утилизируется $0,01-0,2 \%$ солнечной радиации [1].

Разрабатывая проблему генетических форм засоления почв аридных биогеоценозов В. P. Волобуев отмечает, что различные типы (эндогенный, гравитационный, ледниковый, делювиальный, биогенный, техногенный и др.) миграции веществ и солевых масс непосредственно связаны с общими энерго-материальными условиями окружающей среды, формирующиеся не только посредством круговорота веществ, но и затратами солнечной энергии на геохимические и биологические (в том числе и на формирование биомассы) процессы почвообразования [2]. 


\section{Объекты и методика исследования}

Исследование проводились в различной степени засоленных серо-бурых (СиазаньСумгаитский массив) и сероземно-луговых (Сальянская степь) почвах.

В качестве объектов исследования были выбраны естественные биотопы под галофитной растительностью, а также окультуренные ценозы (агроценозы под овощными культурами, лесополосой и посевы зерновых).

Сбор почвенных беспозвоночных проводился по общепринятой методике М. С. Гилярова [3].

Общую энергию аккумулированной в биомассе беспозвоночных животных определяли с учетом энергетических (калориметрических) показателей выявленных групп [4].

Энергетические показатели отдельных групп микробиоты рассчитывались с учетом общей численности микроорганизмов по С. А. Алиеву [1].

Полученные результаты по отдельным биотопам сравнительно анализировались между собой. Такой подход позволяет энергетически оценить участие отдельных экогрупп беспозвоночных животных и микроорганизмов в трансформации энергии аккумулированной в биомассе по отдельным трофическим уровням естественных и окультуренных ценозов.

\section{Обсуждение результатов}

Вначале следует отметить, что поступающие в почву органические остатки галофитной растительности являются по существу основным пищевым и энергетическим ресурсом которые используются почвенными беспозвоночными и микроорганизмами для создания своей биомассы.

Подобно растительности, проявляющие дифференцированную избирательность к минеральным веществам, среди беспозвоночных животных и микробиоты засоленных биотопов также обнаруживается аналогичная дифференцированная адаптация к местам обитания связанная с селективным отношением отдельных групп к потребляемым энергетическим ресурсам [2, 5].

Учитывая, что изучение данного вопроса является приоритетным в области почвенной биоэнергетики, был проведен теоретический анализ и рассчитано количество энергии аккумулированной в биомассе беспозвоночных животных и микроорганизмов на примере засоленных серо-бурых (Сиазань-Сумгаитский массив) и сероземно-луговых (Сальянская степь) почв (Таблица).

Таблица.

ЭНЕРГЕТИЧЕСКИЕ ПОКАЗАТЕЛИ БЕСПОЗВОНОЧНЫХ ЖИВОТНЫХ И МИКРООРГАНИЗМОВ В ЕСТЕСТВЕННЫХ И ОКУЛЬТУРЕННЫХ ЦЕНОЗАХ ИЗУЧАЕМЫХ ПОЧВ (кКаЛ/ $\mathrm{M}^{2}$ )

\begin{tabular}{|c|c|c|c|c|c|c|c|}
\hline & \multicolumn{4}{|c|}{$\begin{array}{c}\text { Серо-бурая почва } \\
\text { (Сиазань-Сумгаитский массив) }\end{array}$} & \multicolumn{3}{|c|}{$\begin{array}{c}\text { Сероземно-луговая почва } \\
\text { (Сальянская степь) }\end{array}$} \\
\hline & 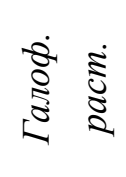 & 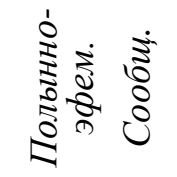 & 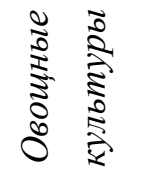 & 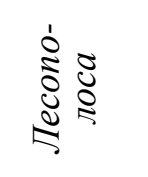 & 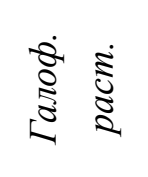 & 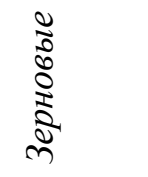 & $\frac{\sqrt{2}}{\frac{2}{5}}$ \\
\hline $\begin{array}{l}\text { Энергия, аккумулированная } \\
\text { в беспозвоночных } \\
\text { жсивотных }\end{array}$ & 466,47 & 2290,78 & 4557,54 & 5544,35 & 3412,52 & 1439,50 & - \\
\hline $\begin{array}{l}\text { Энергия, аккумулированная } \\
\text { в микроорганизмах }\end{array}$ & 6,551 & - & 21,179 & - & 7,276 & 44,072 & 44,464 \\
\hline
\end{tabular}


Расчеты показали, что энергия аккумулированная в сухом веществе 0,1030 г/ $\mathrm{m}^{2}$ беспозвоночных животных сильно засоленной серо-бурой почвы под галофитной растительностью (засоление 1,6\% по плотному остатку) составляет 466,47 кал/м², значительная часть которой 432,22 кал/м² (93,03\%) аккумулирована в насекомых (Insecta) и лишь 6,97\% или 34,25 кал/м² приходится на долю изопод (Isopoda).

В слабо засоленной $(0,4 \%$ - по плотному остатку) целинной почве под полынноэфемеровым сообществом в сухом веществе $0,5103 \quad \mathrm{r} / \mathrm{M}^{2}$ беспозвоночных животных аккумулируется значительно большее количество энергии 2290,78 кал/м².

Большая часть этой энергии - 93,91\% или 2151,27 кал/м ${ }^{2}$ сосредоточена в двух группах - люмбрицидах (Lumbricidae) 969,97 кал/м² - 40,44\% и жесткокрылых насекомых (Coleoptera) - 1150,28 кал/м². Минимальное количество энергии - 131,02 кал/м² (6,09\%) накоплено в изоподах (Isopoda).

По сравнению с целиной, энергия аккумулированная в сухом веществе беспозвоночных

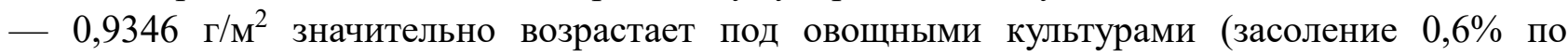
плотному остатку) до 455,54 кал/м ${ }^{2}$ и лесополосой (засоление $0,3 \%$ по плотному остатку) до 5544,35 кал/ м². $^{2}$

Основная часть энергии под овощными культурами сосредоточена в дождевых червях

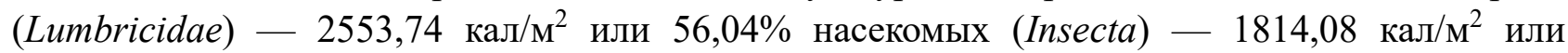
$39,80 \%$, меньшая часть аккумулирована в изоподах (Isopoda) - 189,72 кал/м² или 4,16\%.

В почве лесополосы основная часть энергии аккумулирована в дождевых червях (Lumbricidae) - 5326,37 кал/м² или 96,07\% и изоподах (Isopoda) - 217,98 кал/м² или 3,93\%.

Сероземно-луговые почвы по степени засоления почвы значительно отличаются от предыдущей почвы, и поэтому энергетические показатели беспозвоночных животных будут

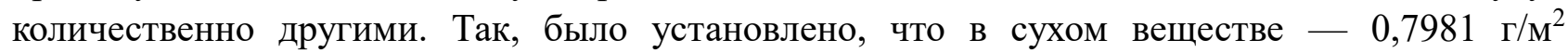
беспозвоночных животных в сильно засоленной (засоление $2,4 \%$ по плотному остатку) почве под галофитной растительностью аккумулирована 3412,52 кал/м² энергии.

Значительное количество этой энергии сосредоточена в насекомых (Insecta) - 2406,18

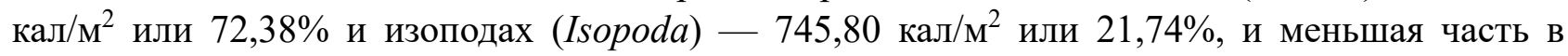
хищных многоножках (Scolopendromorpha) - 260,54 кал/м² или 5,88\%.

На агроценозе под посевами зерновых общая численность беспозвоночных и их биомасса уменьшается до 20 экз $/ \mathrm{m}^{2}$ сухого веса. Соответственно изменяются и их энергетические показатели. Энергия аккумулированная в сухой массе беспозвоночных составляет - 1439,50 кал/м², которая сконцентрирована в трех основных группах: насекомых

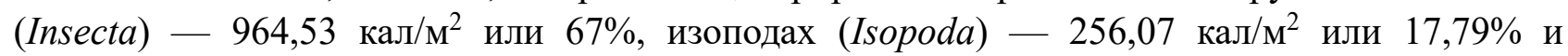
дождевых червях (Lumbricidae) - 218,90 кал/м² или 15,21\%.

Существенную значимость приобретает изучение биоэнергетики микробиологических процессов засоленных почв, которая позволяет раскрыть характерные особенности аккумуляции энергии в микробной массе изучаемых почв [6-12].

Расчеты энергии аккумулированной в биомассе микробиоты серо-бурых почв проводились на примере двух биотопов покрытых галофитной формацией и лишенной растительности (Таблица).

В первом случае общее количество энергии аккумулированная в биомассе $\left(1,078 \Gamma / \mathrm{M}^{2}\right)$ микроорганизмов составило - 6,551 ккал/м². Во втором случае, когда засоленная почва практически лишена растительности энергия аккумулированная в биомассе микроорганизмов $(1,012$ г/м²) уменьшается до - 6,150 ккал/м².

Сероземно-луговые, целинные (солончаковые) почвы аналогично предыдущим развиваются под галофитной растительностью, но с сопутствующей травянистой 
растительностью (зерновые, сложноцветные, крестоцветные) которая свидетельствует о развитие здесь в прошлом лугового процесса почвообразования положительно отражающаяся на жизнедеятельность микробиоты.

По сравнению с засоленной серо-бурой почвой в солончаковой почве микроорганизмы

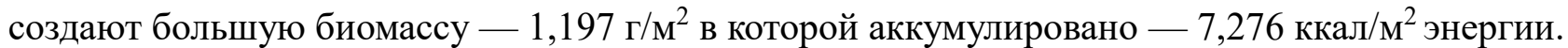

Освоение засоленных почв под различными сельскохозяйственными культурами существенно изменила энергетические показатели микробиоты. В серо-бурой почве под овощными культурами значительно возрастает их биомасса до 3,485 г/м ${ }^{2}$, в которой аккумулируется - 21,179 ккал/м² энергии.

В сероземно-луговой почве в агроценозах под зерновыми и люцерной отмечается

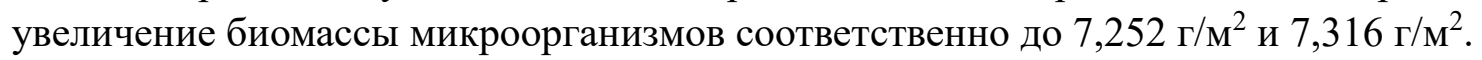

Количественное увеличение биомассы микроорганизмов в обеих агроценозах сопровождается возрастанием их энергетических показателей до 44,072 ккал/м² и 44,464 ккал/м².

Сравнительно анализируя полученные результаты по беспозвоночным животным и микроорганизмам засоленных естественных и окультуренных ценозов серо-бурых и сероземно-уговых почв можно отметить некоторые существенные элементы их жизнедеятельности [5-9].

Во-первых, было установлено, что на засоленных почвах формируются комплексы эвригалинных групп беспозвоночных животных и микробиоты, т. е. адаптивно приспособленных к засоленным биотопам и использующих в качестве энергетических ресурсов остатки галофитной растительности.

Во-вторых, в результате антропогенной деятельности, т. е. окультуривания засоленных почв значительно улучшается среда обитания почвенных организмов.

Постепенно формируются комплексы беспозвоночных животных и микробиоты с широким диапазоном жизнедеятельности, т. е. эврибионтных групп положительно влияющих на плодородие засоленных почв [9].

\section{Bblbodbl}

1. Энергия аккумулированная в биомассе беспозвоночных животных засоленных серо-

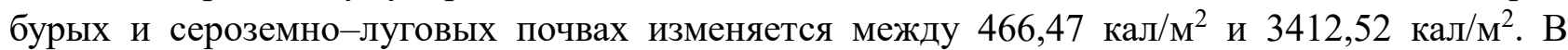
окультуренных вариантах этих почв (под овощными, лесополосой, и зерновыми) в биомассе беспозвоночных аккумулируется соответственно 4557,54-5544,35 кал/м².

2. В биомассе микроорганизмов засоленных серо-бурых и сероземно-луговых почвах

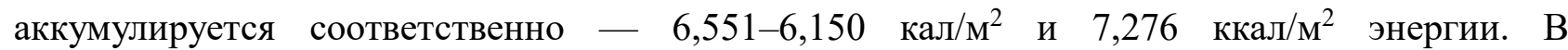
окультуренных вариантах этих почв (под овощными, зерновыми и люцерной) аккумулируется соответственно 21,179 ккал/м² и 44,072-44,464 ккал/м², энергии.

\section{Список литературы.:}

1. Алиев С. А. Энергетика почвообразования: лекция. Новосибирск: НСХИ. 1985. 28 с.

2. Волобуев В. Р. Введение в энергетику почвообразования. М.: Наука, 1974. 128 с.

3. Гиляров М. С. Учет крупных почвенных беспозвоночных (мезофауны) // Методы почвенно-зоологических исследований. М.: Наука, 1975. С. 12-29.

4. Самедов П. А. Энергетические показатели различных биогеоценозов // Материалы II (XII) Всероссийского совещания по почвенной зоологии. М.: Изд-во КМК, 1999. С. 242. 
5. Самедов П. А. Энергетические показатели засоленных почв // Почвы Азербайджана: генезис, география, мелиорация, рациональное использование и экология. Т. XII. Ч. II. Баку: Национальная Академия наук Азербайджана, 2012. С. 509-512.

6. Самедов П. А., Баббекова Л. А., Алиева Б. Б., Мамедзаде В. Т., Садыхова М. Э., Алиева М. М. Биологические показатели и их значение в диагностике засоленных почв аридных биогеоценозов Азербайджана // Вестник Рязанского государственного агротехнологического университета им. П. А. Костычева. 2013. №4. С. 52-56.

7. Самедов П. А., Баббекова Л. А., Алиева Б. Б, Мамедзаде В. Т. Сравнительная характеристика биологических процессов серо-бурых почв естественных и антропогенных ландшафтов Абшеронского полуострова // Биоразнообразие, проблемы экологии Горного Алтая исопредельных регионов: настоящее, прошлое, будущее: мат. межд. конф. ГорноАлтайск. 2008. С. 116-120.

8. Самедов П. А., Баббекова Л. А., Захидова Б. Б. Биологическая характеристика серобурых почв Сиязань-Сумгаитского массива, как показаль плодородия почв // Труды ин-та почвоведения и агрохимии. Т. XVI. Баку: Элм, 2004. С. 422-434.

9. Сейтказиев А. С., Мусаев А. И. Методы улучшения продуктивности засоленных земель // Гидрометеорология и экология. 2010. №3. С. 163-173.

10. Grattan S. R., Grieve C. M. Mineral element acquisition and growth response of plants grown in saline environments // Agriculture, ecosystems \& environment. 1992. V. 38. №4. P. 275300.

11. Qurashi A. W., Sabri A. N. Bacterial exopolysaccharide and biofilm formation stimulate chickpea growth and soil aggregation under salt stress // Brazilian Journal of Microbiology. 2012. V. 43. №3. P. 1183-1191.

12. Kaviani E., Niazi A., Moghadam A., Taherishirazi M., Heydarian Z. Phytoremediation of Ni-contaminated soil by Salicornia iranica // Environmental technology. 2019. V. 40. №3. P. 270281.

\section{References:}

1. Aliev, S. A. (1985). Energetika pochvoobrazovaniya: lektsiya. Novosibirsk, NSKhI, 28. (in Russian).

2. Volobuev, V. R. (1974). Vvedenie v energetiku pochvoobrazovaniya. Moscow, Nauka, 128. (in Russian).

3. Gilyarov, M. S. (1975). Uchet krupnykh pochvennykh bespozvonochnykh (mezofauny). In: Metody pochvenno-zoologicheskikh issledovanii. Moscow, Nauka, 12-29. (in Russian).

4. Samedov, P. A. (1999). Energeticheskie pokazateli razlichnykh biogeotsenozov. In: Materialy II (XII) Vserossiiskogo soveshchaniya po pochvennoi zoologii. Moscow, Izd-vo KMK, 242. (in Russian).

5. Samedov, P. A. (2012). Energeticheskie pokazateli zasolennykh pochv. In: Pochvy Azerbaidzhana: genezis, geografiya, melioratsiya, ratsional'noe ispol'zovanie i ekologiya, v. 12, part II. Baku, Natsional'naya Akademiya nauk Azerbaidzhana, 509-512.

6. Samedov, P. A., Babbekova, L. A., Alieva, B. B., Mamedzade, V. T., Sadykhova, M. E., \& Alieva, M. M. (2013). Biological indicators and its importance in the diagnosis of saline soil of arid biogeocenoses of Azerbaijan. Herald of Ryazan State Agrotechnological University Named after P. A. Kostychev, (4), 52-56.

7. Samedov, P., Bababeyova, L., Alieva, B., \& Mammadzade, V. (2008). Comparative description of biological processes of gray-brown soils of natural and anthropogenic landscapes of Absheron peninsula. In: Bioraznoobrazie, problemy ekologii Gornogo Altaya isopredel'nykh 
regionov: nastoyashchee, proshloe, budushchee: mat. mezhd. konf. Gorno-Altaisk, 116-120. (in Russian).

8. Samedov, P. A., Babbekova, L. A., \& Zakhidova, B. B. (2004). Biologicheskaya kharakteristika sero-burykh pochv Siyazan'-Sumgaitskogo massiva, kak pokazal' plodorodiya pochv. In: Trudy in-ta pochvovedeniya i agrokhimii, 16. Baku, Elm. 422-434.

9. Seitkaziev, A. S., \& Musaev, A. I. (2010). Metody uluchsheniya produktivnosti zasolennykh zemel'. Gidrometeorologiya i ekologiya, (3). 163-173. (in Russian).

10. Grattan, S. R., \& Grieve, C. M. (1992). Mineral element acquisition and growth response of plants grown in saline environments. Agriculture, ecosystems \& environment, 38(4), 275-300.

11. Qurashi, A. W., \& Sabri, A. N. (2012). Bacterial exopolysaccharide and biofilm formation stimulate chickpea growth and soil aggregation under salt stress. Brazilian Journal of Microbiology, 43(3), 1183-1191.

12. Kaviani, E., Niazi, A., Moghadam, A., Taherishirazi, M., \& Heydarian, Z. (2019). Phytoremediation of Ni-contaminated soil by Salicornia iranica. Environmental technology, 40(3), 270-281.

Работа поступила

Принята к публикацุии

в редакциюю 19.02.2019 2. 24.02.2019 2.

Ссылка для циитирования:

Самедов П. А. Биоэнергетика засоленных почв // Бюллетень науки и практики. 2019. Т. 5. №3. C. 112-117. https://doi.org/10.33619/2414-2948/40/14.

Cite as (APA):

Samedov, P. (2019). Bioenergetics of saline soils. Bulletin of Science and Practice, 5(3), 112117. https://doi.org/10.33619/2414-2948/40/14. (in Russian). 